\title{
DISHARMONI DALAM PENGATURAN KURIKULUM, PENDIDIKAN PANCASILA, DAN PENDIDIKAN KEWARGANEGARAAN DI PERGURUAN TINGGI
}

Muh. Ali Masnun, Radhyca Nanda Pratama; Program Studi Ilmu Hukum Universitas Negeri Surabaya, Jl. Ketintang, Ketintang, Kec. Gayungan, Surabaya, Jawa Timur; E-mail: alimasnun@unesa.ac.id

\begin{abstract}
Abstrak
Kurikulum sebagai instrumen yang memuat rencana dan pengaturan mengenai identitas deskripsi mata kuliah, tujuan, isi, bahan pelajaran serta cara yang digunakan dalam penyelenggaraan dan mencapai tujuan pendidikan memiliki peran yang cukup krusial. Penerapan kurikulum Mata Kuliah Wajib Umum (MKWU) di seluruh perguruan tinggi di Indonesia hingga saat ini belum memiliki keseragaman, terutama pada mata kuliah pendidikan Pancasila dan pendidikan kewarganegaraan baik dari sisi nomenklatur pemberian nama mata kuliah maupun beban satuan kredit semester (SKS). Tujuan penelitian ini menganalisis mengenai kurikulum, pendidikan Pancasila, dan Pendidikan Kewarganegaraan dengan menggunakan analisis kajian hukum doktrinal. Pendekatan yang digunakan adalah pendekatan konseptual dan pendekatan perundang-undangan. Disharmoni antara ketentuan Pasal 37 ayat (2) UU Sisdiknas dan Pasal 35 UU Dikti merupakan salah bentuk disharmoni horizontal yang menimbulkan beberapa problematika yuridis antara lain disfungsi hukum, terjadinya perbedaan penafsiran dalam pelaksanaannya, tidak terlaksana secara efektif dan efisien dan dapat menimbulkan ketidakpastian hukum. Adapun upaya peraturan perundang-undangan yakni dengan cara mengubah atau mencabut pasal yang mengalami tidak sinkron oleh lembaga atau instansi yang memiliki kewenangan, namun demikian mekanisme ini memerlukan waktu yang relatif cukup lama karena untuk dapat mengubah suatu peraturan perundang-undangan harus masuk dalam prolegnas dan rangkaian pembentukan peraturana perundang-undangan. Mekanisme atau cara lain adalah dengan menggunakan asas hukum yakni lex posteriori derogat lege priori dan asas lex specialis derogat lege generalis sehingga Pasal 35 UU Dikti dapat mengesampingkan ketentuan Pasal 37 ayat (2) UU Sisdiknas.
\end{abstract}

Kata Kunci: Disharmoni, Pendidikan Pancasila, Pendidikan Kewarganegaraan.

\section{Abstract}

The curriculum as an instrument that contains plans and arrangements regarding the objectives, content, and learning materials as well as the methods used in organizing and achieving educational goals have a quite crucial role. The implementation of the General Obligatory Course (MKWU) curriculum in universities in Indonesia so far does not have uniformity, especially in Pancasila education and citizenship education both in terms of nomenclature for naming subjects and credits. The purpose of this study is to analyze curriculum, Pancasila education, and citizenship education by using analysis of doctrinal law studies. The approach used is the statutory approach and conceptual approach. Disharmony between the provisions of Article 37 paragraph (2) of the UU Sisdiknas and Article 35 of the UU Dikti is a form of horizontal disharmony that causes several juridical problems including legal dysfunction, differences in interpretation in its implementation, not implemented effectively and efficiently and can lead to legal uncertainty. The effort to harmonize legislation is to change or revoke certain articles that have experienced disharmony by the institution or agency authorized to form it, however this method requires a relatively long time because to be able to change a legislation must be included in the National Legislation Program and a series of laws and regulations. Another mechanism or method is to use the legal principle of the lex posteriori derogat lege priori and the lex specialis derogat lege generalis principle so that Article 35 of the Directorate of Higher Education Law can override the provisions of Article 37 paragraph (2) of the National Education System Law.

Keywords: Disharmony, Pancasila Education, Citizenship Education. 


\section{PENDAHULUAN \\ Latar Belakang}

Pendidikan merupakan salah satu penentu kemajuan sebuah bangsa, sehingga secara sadar founding fathers kita telah menentukan bahwa salah satu tujuan yang tertuang pada Pembukaan Undang-Undang Dasar Negara Republik Indonesia Tahun 1945 (UUD NRI 1945) adalah mencerdaskan kehidupan bangsa. Penentuan salah satu tujuan tersebut tentu dengan pertimbangan matang akan pentingnya pendidikan, karena secara alamiah manusia memerlukan pendidikan dalam menjalani kehidupannya. Pendidikan merupakan upaya agar manusia dapat mengembangkan potensi dirinya melalui proses pembelajaran dan/atau cara lain yang dikenal dan diakui oleh masyarakat. Memperhatikan urgensinya pendidikan tersebut, pemerintah memiliki tanggung jawab mengusahakan dan menyelenggarakan satu sistem pendidikan nasional yang meningkatkan keimanan dan ketakwaan serta akhlak sebagaiman diatur dalam Pasal 31 ayat (1) UUD NRI 1945, untuk memenuhi kebutuhan penyelenggaraan pendidikan nasional tersebut, telah diprioritaskan anggaran sebesar 20\% dari total Anggaran Pendapatan dan Belanja Negara (APBN).

Penyelenggaraan sistem pendidikan nasional salah satunya perlu instrumen kurikulum di dalamnya, kurikulum merupakan seperangkat rencana dan pengaturan mengenai identitas, deskripsi, tujuan, isi, dan bahan pelajaran serta cara yang digunakan sebagai pedoman penyelenggaraan kegiatan pembelajaran untuk mencapai tujuan pendidikan tertentu. Penerapan kurikulum Mata Kuliah Wajib Umum (MKWU) di perguruan tinggi di Indonesia hingga saat ini belum memiliki keseragaman, terutama pada mata kuliah pendidikan Pancasila dan pendidikan kewarganegaraan baik dari sisi nomenklatur penamaan mata kuliah maupun beban sistem kredit semester (untuk selanjutnya disebut SKS). Ketentuan kurikulum wajib pendidikan tinggi telah diatur pada Pasal 37 ayat (2) Undang-Undang Republik Indonesia Nomor 20 Tahun 2003 tentang Sistem Pendidikan Nasional (untuk selanjutnya disingkat UU Sisdiknas) bahwa "kurikulum pendidikan tinggi wajib memuat pendidikan agama, pendidikan kewarganegaraan, dan bahasa". Sementara ketentuan kurikulum wajib pendidikan tinggi juga diatur pada Pasal 35 Undang-Undang Republik Indonesia Nomor 12 Tahun 2012 tentang Pendidikan Tinggi (untuk selanjutnya disingkat UU Dikti), bahwa "kurikulum pendidikan tinggi wajib memuat mata kuliah agama, Pancasila, Kewarganegaraan dan bahasa Indonesia".

\section{Rumusan Masalah}

Berdasarkan ketentuan pengaturan tersebut, bahwa terdapat disharmoni pengaturan kurikulum wajib di pendidikan tinggi. Pengaturan yang demikian tentu pada tataran implementasi akan memiliki beragam satu perguruan tinggi. Apalagi Pendidikan Pancasila dan Pendidikan Kewarganegaraan sebagai salah satu pendidikan moral dan karakter untuk mahasiswa dan mahasiswi memiliki substansi materi yang tidak sama. Tujuan penelitian ini untuk menganalisis disharmoni pengaturan dalam kurikulum, pendidikan Pancasila, dan pendidikan kewarganegaraan di perguruan tinggi.

\section{METODE PENELITIAN}

Penulisan artikel ini menggunakan kajian hukum doktrinal atau lazim disebut penelitian hukum normatif yang merupakan penelitian hukum yang mendasarkan analisisnya pada peraturan perundang-undangan yang berlaku dan relevan dengan permasalahan hukum 
yang menjadi fokus penelitian ${ }^{1}$. Elaborasi atas penelitian tersebut dengan berupaya menelusuri baik bahan hukum primer dan bahan hukum sekunder. Bahan hukum primer berupa peraturan perundang-undangan yang terkait dengan isu yang penulis angkat, antara lain UU Sisdiknas dan UU Dikti. Bahan hukum sekunder berupa bahan hukum penunjang bahan hukum primer antara lain buku dan jurnal terkait. Pendekatan yang digunakan dalam penulisan artikel ini adalah pendekatan konseptual dan pendekatan perundang-undangan.

\section{PEMBAHASAN}

Kurikulum memiliki kedudukan yang cukup krusial dalam sebuah proses pendidikan, karena kurikulum sebagai dokumen tertulis yang memuat rencana dana pengaturan terkait tujuan, isi, dan bahan ajar berfungsi untuk mengarahkan ke aktivitas proses pendidikan untuk mencapai tujuan-tujuan pendidikan. Hal ini senada apa yang diungkapkan oleh Nurgiyantoro, bahwa kurikulum memiliki tiga fungsi. Pertama, fungsi kurikulum bagi lembaga pendidikan terdiri dari alat (tool) untuk mencapai tujuan pendidikan yang diinginkan. Kedua, kurikulum dapat mengontrol dan memelihara keseimbangan proses pendidikan. Ketiga, fungsi kurikulum untuk menyiapkan kebutuhan masyarakat (stakeholder) atau lapangan kerja, sehingga kurikulum mencerminkan hal-hal yang menjadi kebutuhan masyarakat. ${ }^{2}$

Urgensi kurikulum dalam proses pendidikan, Indonesia sebagai negara hukum telah memberikan payung hukum mengenai pendidikan sebagaimana diatur dalam UU Sisdiknas. Ketentuan kurikulum pada masing-masing tingkatan pendidikan berbeda satu dengan lain sesuai dengan tujuan yang ingin dicapai. Kurikulum wajib pendidikan sebagaimana diatur dalam Pasal 37 ayat (2) UU Sisdiknas disebutkan bahwa "kurikulum pendidikan tinggi wajib memuat pendidikan kewarganegaraan, pendidikan agama, dan bahasa", sedangkan ketentuan Pasal 35 UU Dikti disebutkan bahwa "kurikulum pendidikan tinggi wajib memuat mata kuliah agama, Pancasila, Kewarganegaraan dan bahasa Indonesia". Ketentuan mana yang akan dijadikan sebagai acuan, Apakah UU Sisdiknas atau UU Dikti, Dapatkah UU Dikti dianggap sebagai peraturan yang lebih khusus sehingga mengenyampingkan ketentuan yang diatur dalam UU Sisdiknas. Berdasarkan kedua ketentuan UU Sisdiknas dan UU Dikti merupakan sebuah disharmoni atau dapat dikatakan peraturan perundang-undangan tidak sinkron. Konsep disharmoni jika kita analisis, maka merupakan lawan kata dari harmoni, atau dalam khasanah ilmu hukum lazim menggunakan istilah harmonisasi, harmonisasi sendiri menjadi sangat sering tercetus dalam disiplin ilmu hukum terutama di Indonesia, bukan tanpa sebab melainkan sering munculnya perbedaan-perbedaan yang bersifat sektoral dalam memaknai dan mengarahkan kepada pembentukan peraturan perundangan-undangan. ${ }^{3}$ Maka disharmoni

1 Kornelius Benuf, Muhamad Azhar, Metodologi Penelitian Hukum sebagai Instrumen Mengurai Permasalahan Hukum Kontemporer, Gema Keadilan, Volume 7, No. 1, 2020, h. 24.

2 Burhan Nurgiyantoro, Dasar-Dasar Pengembangan Kurikulum Sekolah; Sebuah Pengantar Teoritis dan Pelaksanaan, Yogyakarta: BPFE, 1988, h. 45-46.

${ }^{3}$ Ryan Kurniawan, Harmonisasi Hukum Sebagai Perlindungan Hukum Bagi Pekerja Pada Perusahaan Pailit Ditinjau Dari Perspektif Pancasila Sila Ke Lima Jurnal Wawasan Hukum, Vol. 28 No. 01 Februari 2013, h.688. 
merupakan ketidakselarasan, dalam konteks hukum berarti ketidakselarasan norma hukum.

Disharmoni yang terjadi sebagaimana dalam ketentuan kurikulum pendidikan tinggi wajib tersebut, sebagaimana diatur dalam UU Sisdiknas dan UU Dikti dapat menimbulkan beberapa problematika yuridis seperti disfungsi hukum, terjadinya perbedaan penafsiran dalam pelaksanaannya, dan kedua undang-undang tersebut tidak terlaksana secara efektif dan efisien. Hal lain sebagai akibat adanya disharmoni peraturan perundang-undangan juga dapat menimbulkan ketidakpastian hukum. Sebagaimana penulis alami sewaktu menempuh pendidikan Strata 1 (S1) di salah satu perguruan tinggi negeri di Kota Malang, mata kuliah wajib yang diambil salah satunya adalah kewarganegaraan dengan beban 2 SKS. Tidak ada mata kuliah Pendidikan Pancasila. Hal lain yang juga pernah peneliti alami sebagai dosen di salah dua kampus swasta ternama di Kota Surabaya memiliki mata kuliah wajib berbeda, satu dengan mata kuliah PPKn dengan bobot 3 SKS, dan satunya hanya mata kuliah Pendidikan Kewarganegaraan dengan beban 2 SKS. Mana yang benar, tidak ada yang salah jika memberikan argumentasi berdasarkan salah satu UU tersebut, sehingga berimplikasi pada timbulnya perbedaan penafsiran antar perguruan tinggi sehingga tidak ada kepastian hukum. Padahal secara epistimologi baik pendidikan Pancasila dan pendidikan kewarganegaraan merupakan dua mata kuliah yang memiliki cakupan bahasan berbeda, meskipun keduanya tidak terpisahkan satu sama lain.

Mengacu pada gagasan Kusnu Goesniadhie, bahwa faktor-faktor yang menyebakan terjadinya disharmoni dalam peraturan perundang-undangan antara lain:4

1. Kuantitas regulasi (peraturan perundang-undangan terlalu banyak yang diberlakukan;

2. Perbedaan kepentingan dan penafsiran perundang-undangan;

3. Disparitas antara pemahaman teknis dan pemahaman hukum mengenai pemerintahan yang baik;

4. Faktor penghambat hukum yang dihadapi dalam implementasi peraturan perundangundangan, yang terdiri dari mekanisme pengaturan, administrasi pengaturan, antisipasi terhadap perubahan, dan penegakan hukum; dan/atau

5. Tumpang tindih kewenangan dan benturan kepentingan;

Mengacu faktor penyebab disharmoni sebagaimana diungkapkan Kusnu Goesniadhie maka dapat dianalisis yakni huruf b) berkaitan dengan perbedaan kepentingan dan penafsiran, menurut hemat penulis bahwa konsep pendidikan Pancasila dan pendidikan kewarganegaraan mungkin sekali ditafsirkan lain. Memang kedua hal tersebut berbeda dan sekalipun keduanya tidak dapat dipisahkan satu sama lain. Terlepas dari kontroversi kehadiran UU Dikti yang telah menjadi problem sebelum dan sesudah diundangkan, diantaranya mempermasalahkan konstitusionalitasnya.

Menurut bentuknya, bentuk disharmoni UU Sisdiknas dan UU Dikti mengacu apa yang diungkapkan oleh Sidharta, maka termasuk bentuk inkonsistensi secara horizontal dari segi substansi/isi peraturan dapat dimaknai bahwa peraturan secara hierarki sejajar tetapi

\footnotetext{
${ }^{4}$ Kusnu Goesniadhie, Harmonisasi Sistem Hukum Mewujudkan Tata Pemerintahan yang Baik, Malang: Nasa Media, 2010, h. 11.
} 
substansi peraturan yang satu bertentangan dengan substansi peraturan lainnya dan inkonsistensi secara horizontal dari segi substansi dalam satu peraturan yang sama5, misalnya ketentuan Pasal 37 UU Sisdiknas mengenai kurikulum yang tidak memasukan Pancasila sebagai muatan wajib, berpotensi bertentangan dengan ketentuan Pasal 1 UU Sisdiknas yang menyatakan pendidikan nasional merupakan pendidikan yang berdasarkan Pancasila dan UUD 1945 yang berakar pada nilai-nilai agama, kebudayaan nasional Indonesia dan tanggap terhadap tututan perubahan zaman.

Indonesia sebagai negara hukum sebagaimana diatur dalam Pasal 1 ayat 3 UUD NRI 1945, maka salah satu konsekuensi yang dimiliki adalah memiliki produk hukum yang selaras, harmonis (tidak saling bertentangan), tidak tumpang tindih. Produk hukum yang dihasilkan di Indonesia dituntut harmonisasi struktur hubungan-hubungan hukum, substansi-substansi baru pengaturan hukum, dan budaya hukum yang baru. Tanpa adanya harmonisasi sistem hukum, akan memunculkan keadaan tidak dapat menjamin kepastian hukum yang dapat menimbulkan gangguan dalam kehidupan bermasyarakat, ketidaktertiban dan rasa tidak terlindungi. ${ }^{6}$ Dalam perspektif demikian masalah kepastian hukum, ketertiban hukum dan perlindungan hukum akan dirasakan sebagai kebutuhan yang hanya dapat terwujud melalui harmonisasi sistem hukum untuk dapat dapat dikatakan sebagai hukum yang baik.

Lon Fuller sebagai dikutip oleh Munir Fuady, mengungkapkan bahwa terdapat 8 (delapan) kriteria hukum yang baik (hukum dalam konteks ini dikonsepsikan sebagai peraturan perundang-undangan yang merupakan produk dari legislatif), antara lain kriterianya meliputi: ${ }^{7}$

a. Hukum harus ditaati oleh semua orang, asas persamaan di dalam hukum;

b. Hukum harus disosialisasikan baik pada masyarakat maupun pejabat daerah;

c. Hukum harus berlaku ke depan (futuristik), dengan arti hukum tidak berlaku pasang surut;

d. Kaidah hukum harus ditulis secara jelas (tidak ambigu, tidak bermakna ganda), sehingga dapat diketahui dan diterapkan secara benar;

e. Hukum harus menghindari diri dari kontradiksi-kontradiksi;

f. Hukum tidak diperbolehkan mewajibkan sesuatu yang tidak mungkin dapat dipenuhi;

g. Hukum harus memiliki sifat konsisten, sehingga masyarakat memiliki kepastian hukum.

h. Tindakan para aparat pemerintah dan penegak hukum harus sesuai dengan hukum yang berlaku.

\footnotetext{
${ }^{5}$ Shidarta dkk, Narasi Inisiatif Harmonisasi Sistem Hukum Pengelolaan Wilayah Pesisir Indonesia, Menuju Harmonisasi Sistem Hukum Sebagai Pilar Pengelolaan Wilayah Pesisir Indonesia, Jakarta: Kementerian Perencanaan Pembangunan Nasional/Badan Perencanaan Pembangunan Nasional, Departemen Kelautan dan Perikanan, Departemen Hukum dan Hak Asasi Manusia bekerja sama dengan Coastal Resources Management Project/Mitra Pesisir, 2005, h. 62.

${ }^{6}$ Aditya Yuli Sulistyawan, Urgensi Harmonisasi Hukum Nasional Terhadap Perkembangan Hukum Global Akibat Globalisasi, Jurnal Hukum Progresif, Vol. 7, No. 2, Oktober 2019, h. 175.

${ }^{7}$ Munir Fuady, Teori Negara Hukum Modern (Rechtsaat), Bandung: Refika Aditama, 2011, h. 9.
} 
Upaya harmonisasi peraturan perundang-undangan, secara teori dapat dilakukan menggunakan dua mekanisme yakni upaya preventif dan represif. Pertama, upaya preventif dimaknai sebagai upaya yang bisa dilakukan sebelum terjadinya disharmoni peraturan perundang-undangan. Disharmoni sebagaimana dimaksud terjadi karena inkonsistensi norma hukum dapat menimbulkan problematika hukum. Disharmoni peraturan perundangundangan dapat dicegah dengan melakukan harmonisasi. Upaya harmonisasi dengan kajian secara mendalam baik dari sisi materil dan formil setiap materi muatan peraturan perundang-undangan. Harmonisasi materiil tentu materi muatan rancangan peraturan perundang-undangan dengan Pancasila, UUD NRI 1945, peraturan perundang-undang lain, dan asas peraturan perundang-undangan. Aspek formil berarti teknik penyusunan peraturan perundang-undangan sebagaimana dalam Undang-Undang Republik Indonesia Nomor 15 Tahun 2019 tentang Perubahan Atas Undang-Undang Republik Indonesia Nomor 12 Tahun 2011 tentang Pembentukan Peraturan Perundang-Undangan. Berkaitan dengan permasalahan UU Sisdiknas dan UU Dikti tentu tidak bisa menggunakan upaya ini sebagai salah satu mekanisme harmonisasi antara keduanya, karena kedua undang-undang tersebut telah sama-sama diundangkan dan diberlakukan.

Kedua adalah upaya represif jika peraturan perundang-undangan telah diundangkan dan diberlakukan. Mekanisme yang kedua ini lebih sesuai untuk permasalahan UU Sisdiknas dan UU Dikti, pertama dapat dilakukan dengan cara mengganti, mengubah atau bahkan mencabut pasal tersebut yang mengalami disharmoni oleh lembaga atau instansi yang berwenang membentuknya, namun demikian mekanisme tersebut memerlukan waktu yang relatif cukup lama, oleh karena itu untuk dapat mengubah suatu peraturan perundangundangan harus masuk dalam Program Legislasi Nasional (Prolegnas) dan rangkaian pembentukan peraturana perundang-undangan. Kedua, cara lain yang bisa digunakan adalah dengan mengimplementasikan asas hukum ataupun doktrin hukum. Asas-asas penemuan hukum sangat diperlukan dalam penelitian terhadap harmonisasi peraturan perundang-undangan. Konteks disharmoni UU Sisdiknas dan UU Dikti dapat menggunakan dua asas, pertama asas lex posteriori derogat lege priori yang maknanya bahwa peraturan perundang-undangan yang lebih baru, mengesampingkan peraturan perundang-undangan yang diundangkan lebih dulu (lama). Hal ini senada dengan yang diungkapkan oleh Bagir Manan, bahwa asas lex posteriori derogat lege priori memuat prinsip-prinsip, prinsip tersebut antara lain adalah: 8

a. Peraturan hukum yang baru harus setingkat atau lebih tinggi tingkatannya dari aturan hukum yang lebih dulu;

b. Peraturan hukum baik yang baru dan yang lama harus mengatur hal yang sama.

Dalam konteks ini dimaksudkan guna mencegah dualisme yang dapat menimbulkan ketidakpastian hukum. Dari aspek hukum, peraturan lama yang serupa tidak dapat berlaku lagi sesudah aturan hukum yang baru mulai diberlakukan.

Kedua, asas lex specialis derogat lege generalis yang maknanya bahwa peraturan perundang-undangan yang lebih khusus (spesifik) cakupannya akan mengesampingkan

8 Bagir Manan, Hukum Positif Indonesia, Yogyakarta: UII Press, 2004, h. 59. 
peraturan perundang-undangan yang lebih umum (general). Menurut Sidharta, prinsip ini dapat menjadi alternatif untuk menyelesaikan ketika terjadinya inkonsistensi secara horizontal dari segi substansi peraturan, dimana dalam konteks ini beberapa peraturan secara hierarki sejajar/setingkat namun substansi peraturan yang satu lebih umum dibandingkan substansi peraturan yang lain9. Berdasarkan dua asas tersebut, maka UU Dikti dapat mengesampingkan UU Sisdiknas dengan dua alasan utama bahwa UU Dikti lahir setelah UU Sisdiknas sehingga UU Dikti dapat mengesampingkan UU Sisdiknas. UU Dikti juga lebih spesifik mengatur khusus pendidikan tinggi saja, tetapi UU Sisdiknas mencakup semua tingkatan pendidikan, mulai pendidikan dasar, pendidikan menengah dan pendidikan tinggi sehingga UU Dikti dapat mengesampingkan UU Sisdiknas dalam hal kurikulum wajib pendidikan tinggi.

Penerapan 2 (dua) jenis asas preferensi di atas (vide asas Lex Posteriori Derogat Lege Priori dan asas Lex Specialis Derogat Lege Generalis) guna mengatasi terjadinya disharmoni UU Sisdiknas dan UU Dikti merupakan wujud untuk mencapai salah satu tujuan hukum yakni kepastian hukum. Nurul Qamar mengungkapkan, bahwa secara umum tujuan hukum ada 3 (tiga) yakni keadilan, kemanfaatan, dan kepastian hukum. Ketiga-tiganya lazim disebut sebagai tujuan universal daripada hukum. ${ }^{10}$ Implikasi lain dari terjadinya disharmoni pada 2 (dua) undang-undang tersebut (vide UU Sisdiknas dan UU Dikti) adalah ketidakpastian hukum. Ada 2 (dua) unsur paling penting dalam hukum yang harus dianut oleh suatu negara dengan tujuan agar peraturan yang akan/telah dibuat dan diundangkan oleh pembentuk undang-undang tidak bertentangan dengan prinsip negara hukum, 2 (dua) unsur tersebut yakni kepastian (certainty) dan prediktif.11 Artinya suatu produk hukum berupa undang-undang haruslah jelas sesuai hierarki urutannya dan materi muatannya konsisten serta tidak bertentangan baik secara horizontal maupun vertikal sehingga memberikan kepastian hukum bagi masyarakat. Akibat dari terjadinya disharmoni UU Sisdiknas dan UU Dikti adalah menimbulkan ketidakpastian hukum bagi penyelenggara pendidikan tinggi dalam hal penerapan kurikulum pendidikan tinggi, khususnya pada mata kuliah pendidikan Pancasila dan pendidikan Kewarganegaraan.

Senada dengan pendapat yang dikemukakan oleh Munir Fuady, Jan Michael Otto sendiri menggunakan istilah kepastian hukum dengan istilah real legal certainty atau kepastian hukum yang nyata. Kepastian hukum yang nyata pada dasarnya tidak hanya mencakup kepastian hukum yuridis tetapi juga termasuk 4 (empat) indikator lain sebagai berikut: 12

1. Adanya peraturan perundang-undangan yang konsisten, jelas, serta mudah diakses (diperoleh). Peraturan perundang-undangan tersebut diterbitkan oleh dan/atau diakui negara.

2. Bahwa Lembaga dan instansi pemerintah benar benar menerapkan peraturan perundang-undangan tersebut secara konsisten, tunduk dan taat.

\footnotetext{
${ }^{9}$ Shidarta dkk, Op. Cit, h. 64.

${ }^{10}$ Nurul Qamar, Hak Asasi Manusia dalam Negara Hukum Demokrasi (Human Rights in Democratiche Rechtstaat), Jakarta: Sinar Grafika, 2016, h. 16.

${ }^{11}$ Munir Fuady, Op. Cit, h. 11.

${ }^{12}$ Sulistyowati Irianto dkk, Kajian Sosio-Legal, Bali: Pustaka Larasan, 2012, h. 121.
} 
3. Bahwa pada prinsipnya bagian terbesar dan mayoritas dari masyarakat menyetujui materi muatan isi peraturan perundang-undangan, oleh sebab itu mereka menyesuaikan dalam berperilaku sebagaimana yang ditentukan dalam peraturan perundangundangan tersebut.

4. Bahwa hakim pada pengadilan harus mempunyai indepedensi serta integritas dalam proses memeriksa, mengadili, dan memutus perkara dengan menerapkan peraturan perundang-undangan dengan konsisten, dengan tetap memperhatikan hukum yang hidup dimasyarakant.

Salah satu cakupan indikator untuk mewujudkan kepastian hukum yang nyata menurut Jan Michael Otto, yakni adanya peraturan perundang-undangan yang konsisten jelas, serta mudah diperoleh. Peraturan perundang-undangan tersebut diterbitkan oleh dan/atau diakui negara. Mengacu dari salah satu dari indikator tersebut, penyebab terjadinya disharmoni dalam UU Sisdiknas dan UU Dikti adalah terdapat inkonsistensi/disharmoni materi muatan dalam UU Sisdiknas dengan UU Dikti mengenai penyelenggaraan muatan kurikulum pendidikan tinggi yakni pada perbedaan aspek teknis pengaturan muatan mata kuliah Pendidikan Pancasila dengan Pendidikan Kewarganegaraan sehingga di lain hal menurut penulis masyarakat tidak mendapatkan kepastian hukum salah satunya adalah melalui harmonisasi. Harmonisasi hukum adalah upaya atau proses yang hendak mengatasi batasan-batasan perbedaan, hal-hal yang bertentangan dan kejanggalan dalam hukum. Upaya atau proses untuk merealisasi keselarasan, kesesuaian, keserasian, kecocokan, keseimbangan diantara norma-norma hukum didalam peraturan perundang-undangan sebagai sistem hukum dalam satu kesatuan kerangka sistem hukum nasional.13

Menurut Kusnu Goesniadhie ${ }^{14}$ ada lima langkah yang harus dilakukan dalam pengharmonisasian. Pertama, mengidentifikasi letak disharmoni hukum dalam penerapan peraturan perundang-undangan. Kedua, mengidentifikasi penyebab terjadinya disharmonisasi hukum. Ketiga, upaya penemuan hukum dengan menggunakan metode penafsiran dan metode konstruksi hukum untuk mengubah keadaan hukum yang disharmoni menjadi harmoni. Keempat, upaya penalaran hukum agar hasil penafsiran dan konstruksi hukum tersebut masuk akal atau memenuhi unsure logika. Kelima, penyusunan argumentasi yang rasional dengan mempergunakan pemahaman tata pemerintahan yang baik untuk mendukung dan menjelaskan hasil penafsiran hukum, konstruksi hukum, dan penalaran hukum.

\footnotetext{
${ }^{13}$ Sapto Budoyo dalam Indriati Amarini, Evaluasi Aktualisasi Pancasila Melalui Harmonisasi Hukum, Jurnal Kosmik Hukum Vol. 17 No. 2 Juni 2017, h. 86.

${ }^{14}$ Kusnu Goesniadhie, Harmonisasi Sistem Hukum: Mewujudkan Tata Pemerintahan Yang Baik. Malang: Nasa Media, 2010, h. 12-13.
} 


\section{PENUTUP}

\section{Kesimpulan}

Berdasarkan hasil pembahasan yang telah diuraikan maka dapat disimpulkan bahwa disharmoni antara ketentuan Pasal 37 ayat (2) UU Sisdiknas dan Pasal 35 UU Dikti merupakan salah bentuk disharmoni horizontal yang menimbulkan beberapa problematika yuridis antara lain disfungsi hukum, terjadinya perbedaan penafsiran dalam pelaksanaannya, tidak terlaksana secara efektif dan efisien dan dapat menimbulkan ketidakpastian hukum. Adapun upaya yang bisa dilakukan ketika sebuah peraturan perundang-undangan disharmoni adalah melalui, mengubah atau mencabut Pasal $35 \mathrm{UU}$ Dikti yang mengalami disharmoni oleh lembaga atau instansi yang memiliki kewenangan untuk membentuknya, namun demikian mekanisme ini memerlukan waktu yang relatif cukup lama karena untuk dapat mengubah suatu peraturan perundang-undangan harus masuk dalam prolegnas dan rangkaian pembentukan peraturana perundang-undangan. Mekanisme atau cara lain adalah dengan menggunakan asas hukum yakni lex posteriori derogat lege priori dan asas lex specialis derogat lege generalis sehingga Pasal 35 UU Dikti dapat mengesampingkan ketentuan Pasal 37 ayat (2) UU Sisdiknas.

\section{Saran}

Berdasarkan hasil simpulan, maka penulis mencoba memberikan rekomendasi yang dapat dijadikan pertimbangan. Pertama, bagi pemerintah perlu lebih cermat dan jeli dalam hal penyusunan peraturan perundang-undangan, sehingga tidak saling bertentangan (disharmoni) dengan perundang-undangan lain yang berlaku. Bagi Pembentuk UndangUndang, agar segara melakukan perubahan dalam subtansi materi muatan UU Sisdiknas dan UU Dikti mengenai pengaturan kurikulum pendidikan tinggi terkait matakuliah pendidikan Pancasila dan pendidikan kewarganegaraan. Bagi perguruan tinggi seyogyanya menggunakan ketentuan Pasal 35 UU Dikti sebagai kurikulum wajib di masing masing program studi. 


\section{DAFTAR PUSTAKA}

\section{Buku:}

Benuf, Kornelius Muhamad Azhar, Metodologi Penelitian Hukum sebagai Instrumen Mengurai Permasalahan Hukum Kontemporer, Gema Keadilan, Volume 7, No. 1, 2020,

Fuady, Muni, Teori Negara Hukum Modern (Rechtstaat), Bandung: Refika Aditama, 2011.

Goesniadhie, Kusnu, Harmonisasi Sistem Hukum Mewujudkan Tata Pemerintahan yang Baik, Malang: Nasa Media, 2010.

Irianto, Sulistyowati, dkk, Kajian Sosio-Legal, Bali: Pustaka Larasan, 2012

Manan, Bagir, Hukum Positif Indonesia, Yogyakarta: UII Press, 2004.

Nurgiyantoro, Burhan, Dasar-Dasar Pengembangan Kurikulum Sekolah; Sebuah Pengantar Teoritis dan Pelaksanaan, Yogyakarta: BPFE, 1988.

Shidarta, dkk, Narasi Inisiatif Harmonisasi Sistem Hukum Pengelolaan Wilayah Pesisir Indonesia, Menuju Harmonisasi Sistem Hukum Sebagai Pilar Pengelolaan Wilayah Pesisir Indonesia, Jakarta: Kementerian Perencanaan Pembangunan Nasional/Badan Perencanaan Pembangunan Nasional, Departemen Kelautan dan Perikanan, Departemen Hukum dan Hak Asasi Manusia bekerja sama dengan Coastal Resources Management Project/Mitra Pesisir, 2005.

\section{Jurnal}

Amarini, Indriati, Evaluasi Aktualisasi Pancasila Melalui Harmonisasi Hukum, Jurnal Kosmik Hukum Vol. 17 No. 2 Juni 2017

Kurniawan, Ryan, Harmonisasi Hukum Sebagai Perlindungan Hukum Bagi Pekerja Pada Perusahaan Pailit Ditinjau Dari Perspektif Pancasila Sila Ke Lima, Jurnal Wawasan Hukum, Vol. 28 No. 01 Februari 2013

Yuli Sulistyawan, Aditya, Urgensi Harmonisasi Hukum Nasional Terhadap Perkembangan Hukum Global Akibat Globalisasi, Jurnal Hukum Progresif, Vol. 7, No. 2, Oktober 2019.

\section{Peraturan Perundang-Undangan:}

Undang-Undang Republik Indonesia Nomor 20 Tahun 2003 tentang Sistem Pendidikan Nasional

Undang-Undang Republik Indonesia Nomor 12 Tahun 2012 tentang Pendidikan Tinggi 